\title{
Acute lymphocytic leukemia in children: revision and use of clinical forms of treatment by means of medication
}

\author{
Elvys José Borba da Costa ${ }^{1}$, Andrezza Fabianni Pedrosa dos Santos Lima ${ }^{2}$, Emilly Tainá Batista da \\ Silva ${ }^{3}$, Emivaldo Batista da Silva ${ }^{4 *}$, Joana Bulhões Alvares da Silva Lima ${ }^{5}$, Maria Talita Bernardo \\ Silva $^{6}$, Wanderson Cleyton da Silva ${ }^{7}$, Victor Daniel Barros da Silva ${ }^{8}$, Guilherme Expedito Rosendo \\ da Silva ${ }^{9}$, Jacicleide Maria de Souza ${ }^{10}$, Vivian Helen de Albuquerque ${ }^{11}$, Arlan Cassio de Aguiar ${ }^{12}$, \\ Rute Maria Siqueira Silva ${ }^{13}$, Camilla Guadallupe de Oliveira Lima ${ }^{14}$, Júlio César da Silva Bruce ${ }^{15}$, \\ Lyzandra Leticya de Lima Costa ${ }^{16}$, Eloizy Victoria da Silva ${ }^{17}$, Valeria Correia Barbosa ${ }^{18}$, Valquíria \\ da Silva Gomes ${ }^{19}$,Emanuella Barros de Souza Oliveira Alvares ${ }^{20}$, Márlison José Lima de Aguiar ${ }^{21}$
}

1,4,5,11,15,16 Department of Pharmaceutical Sciences, University Center of Vitória de Santo Antão - (UNIVISA) Vitória de Santo Antão, Brazil.

2,6,9 Department of Nutrition, University Center of Vitória de Santo Antão (UNIVISA), Vitória de Santo Antão, Pernambuco, Brazil 7,10,12 Department of Full Degree in Biology, University Center of Vitória de Santo Antão (UNIVISA), Vitória de Santo Antão, Brazil 8 Department of Physical Education, UNIBRA- Recife- PE

13,14,18,19 Department of Bachelor of Nursing, University Center of Vitória de Santo Antão (UNIVISA)

17 Department of Biomedicine, University Center of Vitória de Santo Antão (UNIVISA)

18 Department of Biology, Center for Biological Sciences, Professor of the Degree course in Biology, University Center of Vitória de Santo Antão (UNIVISA), Vitória de Santo Antão, Brazil

19 Department of Biomedicine, Center of Health and Education Professor of the University Center of Vitória de Santo Antão - UNIVISA

E-mail adresses: elvisborba1@gmail.com1 (Elvys José Borba da Costa), andrezzafpslima@hotmail.com2 (Andrezza Fabianni Pedrosa dos Santos Lima), emilly.taina@hotmail.com3 (Emilly Tainá Batista da Silva), emivaldobatista4@gmail.com4 (Emivaldo Batista da Silva), joanafarmacia2018@gmail.com5 (Joana Bulhões Alvares da Silva Lima), mariatalita965@outlook.com6 (Maria Talita Bernardo Silva), professorwanderson2201@gmail.com7 (Wanderson Cleyton da Silva), victor-daniel.0@hotmail.com8 (Victor Daniel Barros da Silva), guilhermenutri1@gmail.com9 (Guilherme Expedito Rosendo da Silva), jacicleidesouza.07@hotmail.com10 (Jacicleide Maria de Souza), vivianalbuquerque902@gmail.com11 (Vivian Helen de Albuquerque), arlan.aguiar@hotmail.com12 (Arlan Cassio de Aguiar), rutesiqueira06@gmail.com13 (Rute Maria Siqueira Silva), camillaguadallupe@gmail.com14 (Camilla Guadallupe de Oliveira Lima), julio.2017186009@univisa.edu.br15 (Júlio César da Silva Bruce), lyzandra.2017286033@univisa.edu.br16 (Lyzandra Leticya de Lima Costa), eloizyv@gmail.com17 (Eloizy Victoria da Silva), valeriacorreiabarbisa2@gmail.com18 (Valeria Correia Barbosa), kilgomessilva10@gmail.com19 (Valquíria da Silva Gomes), emanuella.barros@hotmail.com20 (Emanuella Barros de Souza Oliveira Alvares), marlisonaguiar@yahoo.com.br21(Márlisson José Lima de Aguiar)

${ }^{*}$ Corresponding author

\section{To cite this article:}

Costa, E.J.B.; Lima, A.F.P.S.; Silva, E.T.B.; Silva, E.B.; Lima, J.B.A.S.; Silva, M.T.B.; Silva, W.C.; Silva, V.D.B.; Silva, G.E.R.; Souza, J.M.; Albuquerque, V.H.; Aguiar, A.C.; Silva, R.M.S.; Lima, C.G.O.; Bruce, J.C.S.; Costa, L.L.L.; Silva, E.V.; Barbosa, V.C.; Gomes, V.S.; Álvares, E.B.S.O.; Aguiar, M.J.L. Acute lymphocytic leukemia in children: revision and use of clinical forms of treatment by means of medication. International Journal of Sciences. Vol. 3, No. 1, 2022, pp.79-83. ISSN 2763-5392.

Received: 11 24, 2021; Accepted: 12 26, 2021; Published: 01 15, 2022

\begin{abstract}
This article thematizes treatments in children affected by Acute Lymphocytic Leukemia. For this, treatment in patients from low-risk and high-risk groups will be addressed to the importance of diagnosis, bringing the expected results. Aiming at the process that the child patient receives, from the diagnostic to the treatments developed to reach the cure. This study was conducted from a literature review perspective, which consists of developing a theoretical basis, in the treatment of a research problem that can be answered in the analysis of a published literature. Therefore, this article is based on obtaining the study about articles that described several cases of acute lymphocytic leukemia. During this study it was possible to understand the results through treatment of patients with different degrees of the disease, each with its peculiarities, symptoms and treatment
\end{abstract}


2 Costa, E.J.B.; Lima, A.F.P.S.; Silva, E.T.B.; Silva, E.B.; Lima, J.B.A.S.; Silva, M.T.B.; Silva, W.C.; Silva, V.D.B.; Silva, G.E.R.; Souza,

J.M.; Albuquerque, V.H.; Aguiar, A.C.; Silva, R.M.S.; Lima, C.G.O.; Bruce, J.C.S.; Costa, L.L.L.; Silva, E.V.; Barbosa, V.C.; Gomes, V.S.;

Alvares, E.B.S.O.; Aguiar, M.J.L. Acute lymphocytic leukemia in children: revision and use of clinical forms of treatment by means of medication...

due to the disease. It also reinforces the importance of the diagnosis for the disease to be diagnosed and the indicated treatments are effective and positive, so in this study, it was important to know and understand the treatment known by GBTLI-99 that acts by degree of patient so you could get to the results of this search.

Keywords: Pharmacotherapy. GBTLI-99 protocol. Lymphocytic leukemia in children.

\section{Introduction}

Leukemia is a malignant cancer of white cells in the blood, leukocytes. Starting in the bone marrow and spreading throughout the human body, preventing the production of platelets, red blood cells and also white blood cells (INSTITUTO NACIONAL DO CÂNCER, 2021).

In Brazil, leukemia affects the groups of children and adolescents, reaching about $30 \%$ of tumors. In 2005 , deaths in this age group due to the disease were estimated at $8 \%$ (OLIVEIRA, DINIZ, VIANA, 2004; INCA, 2021). Leukemias are the most common neoplasms in childhood, and acute lymphocytic leukemias (ALL) account for $75 \%$ of childhood leukemias (FARIAS and CASTRO, 2004).

At the same time, it is known that pharmacological treatments have contributed to the therapy of this neoplasm more effectively, due to the progress in the development of medications, which, consequently, have progressively contributed to a higher survival rate of patients; treatment and adequacy. The need to understand important aspects such as the process that is made from when the diagnosis is made, to the process of explaining to patients and their parents, as well as the entire structure adopted by the medical and nursing team, up to the GBTLI-99 protocol, adopted and, essential for the treatment being performed by medications (CAZÉ, BUENO, SANTOS, 2010).

We propose to investigate acute lymphocytic leukemia (ALL) due to its higher incidence in children, and it has large bibliographicproductionsthat help understanding, however there are still gaps that leave open questions that need to be answered how pharmacological treatment can help in the cure of patients with ALL and what are the risks for the possible development of a secondary cancer? In 2005, deaths in this age group due to the disease were estimated at $8 \%$ (OLIVEIRA, DINIZ, VIANA, 2004; INCA, 2021).

Thus, the present study analyzed the forms that are made the diagnosis of Acute Lymphocytic Leukemia (ALL) and the treatments that should be made after the precise diagnosis for this neoplasm, which consequently usually occurs in children from two to five years of age, being more frequent in males and white skin.

\section{Methodology}

The research corresponds to a literature review that aims at a study and finding a solution to the problem, using rational and systematic procedures.

For the development of the review, descriptors were used in the research, such as: medication. pharmacotherapy. GBTLI-99 protocol. Lymphocytic leukemia in children. With this, articles were collected with current publications between 2004 and 2021.

Data collection occurred through research in databases and research platforms, which gathered the largest number of materials. Platforms such as CAPES, Medline, SciELO and others were used, and for this purpose the focus of the collection will be qualitative, in order to bring in-depth information on the subject, with an integrated perspective. Thus, as this is a review of the literature, it did not have the need to go through an Ethics Committee.

\section{Results and Discussion}

\section{The disease (ALL)}

Over the years, studies have been conducted on the various types of neoplasms that exist, however, the whole process to know for sure about the diagnosis is indispensable. Therefore, with regard to the diagnosis of lymphocytic leukemia, where it develops from primitive lymphocytes, which can be found in different stages of development (HAMERSCHLAK, 2008).

Acute lymphological leukemia (ALL) corresponds to a malignant neoplasm that originates in the bone marrow, and occurs by unregulated proliferation in the production of differentiated cells compromising maturation. The pathology affects children, adolescents and adults. In addition, the disease originates from a single progenitor cell that may be "damaged" and results in the suppression of normal hematopoiesis, because of lymphoblast accumulation (SILVA, SOUSA, CARDOSO, 2018).

\section{The diagnosis of ALL}

The diagnosis of childhood cancer is a complex process and many variables seem to influence it. Early detection and prompt initiation of treatment play an important role in reducing treatment mortality and morbidity. (ALMEIDA, 2009). In a sense, the diagnosis of leukemia usually begins with the anamnesis of the patient, that is, it occurs at first by observing simple symptoms, and that in some respects can be confused with other diseases, such as a simple virus, or bacterial infection, anemias of varying degrees, among other common diseases in this age group, LLA assumes a different perspective around the performance of specific tests to identify them, considering that ALL almost always has its late diagnosis, possibly hindering its chances of cure(SILVA, SOUSA, CARDOSO, 2018).

At the laboratory level, we can observe that when a large proliferation of young cells occurs, the bone marrow becomes overloaded, and consequently decreases the production of erythrocytes and platelets, which in the vast 
majority of patients have anemia and thrombocytopenia. As a consequence of the low production of these cells, the patient with ALL also needs to monitor coagulation factors, because due to the low production of the cells they generate (CAZÉ, BUENO, SANTOS, 2010).

Then, other laboratory tests are performed, which help classify the type of leukemia, determine the severity of the disease and prognosis. To do so, the following tests are performed:

The Blood Count has in its structuring the identification of normocytic and normochromic anemias and thrombocytopenia. That is, this type of process works in the count of leukocytes that can sometimes be too high, normal or decreased. Leukocyte count can range from 100 to 1 million leukocytes $/ \mathrm{mm}^{3}, 53 \%$ have less than $10,000,30 \%, 10$ to 49,000 , and $17 \%$ more than 50,000 leukocytes $/ \mathrm{mm}^{3}$ (ALMEIDA, 2009).

If the blood count is altered, the Myelogram is performed, which, in turn, is the test that is based on the collection of a small amount of blood, which is collected inside the bone marrow bone, this collection procedure is performed with the patient lying or sitting as is the case of the examination performed in children. (children). On this, it is known that the study of this tissue reveals normal hematopoietic substitution by immature leukemic cells. Diagnosis is confirmed when more than $25 \%$ to $30 \%$ of nucleated cells are blasts (ALMEIDA, 2009).

Subsequently, the cytogenetic examination is done, which is also one of the methods to diagnose a patient with Acute Lymphological Leukemia, this test in turn will analyze the specific changes of the cells, allowing to know what is the subtype of the disease, so that it can identify whether or not it is an acute leukemia (ALMEIDA, 2009); and, also, the immuno phenotyping method is performed, that is, to use the laser technique that allows the study of a population of cells, which routinely determine its physical and biological characteristics, to thus direct both the diagnosis and treatment of leukemias and lymphomas (ALMEIDA, 2009).

All this is to make a complete and accurate diagnosis of acute lymphoblastic leukemia is important to determine its subtype. T-cell lymphoblastic leukemia tends to be more aggressive, thus requiring more intensive treatment than the "common" form of B-cell lymphoblastic leukemia, where it has a different treatment (CAVALCANTE, et al., 2017).

However, it is observed that the classification of leukemias is based on the chemical cytochemical analysis of neoplastic and morphological cells. However, the difficulty in classifying some patients has led to the search for other ways to diagnose.

\section{Therapy for ALL}

Initial treatment for ALL in children begins with medications such as vincristine and prednisone, which causes remission in almost all children. Still, if this initial therapeutic treatment does not reach the expected result, or, if it is done, about $75 \%$ of the children will relapse within an average of 2 years, even if the tests show a negative result (BRAZILIAN ASSOCIATION OF LYMPHOMA AND LEUKEMIA, 2020).

In addition to this initial treatment can be done through chemotherapy consisting of the use of drugs, with the aim of killing cancer cells. And depending on the type of leukemia, only one type of drug can be administered, or even an association of two or more drugs (INSTITUTOONCOGUIA, 2021).

In the case of chemotherapy treatment, it can happen in several ways by Oral Administration: that will consist of use of tablets. It can vary is to have an intravenous administration: that is, through an injection, given directly into a vein: and intravenous. Which is characterized by the use of a catheter, which is deliberately placed in a large vein, in the upper part of the chest; the catheter will be useful for patients who need many treatments, thus facilitating the process with the administration of drugs inserted in the catheter (CAZÉ, et al., 2010).

A person with acute leukemia needs to be treated immediately. And the main purpose of treatment is tumor remission. Therefore, when the signs and symptoms disappear, additional treatments may be administered. Treatment is termed in this case as maintenance therapy, that is, it is performed to kill all leukemia cells that may have survived the first two early stages of treatment, with the aim of preventing the return of leukemia (CAZÉ, et al., 2010).

\section{Treatment by protocol of the Brazilian Group of Treatment of Childhood Leukemia (GBTLI-99)}

With the Treatment by the Protocol of the Brazilian Group for the Treatment of Childhood Leukemia (GBTLI99), this protocol is based on the use of an x classification of patients, based on the risk of disease recurrence, that is, in agreement with hematological parameters and genetic factors, in addition to the differentiated treatment for each risk group, thus performing a whole investigative structure that seeks to see each group and the correct way to file the due treatment (CAZÉ, et al., 2010).

In this type of protocol, there is a subdivision of patients, thus having a distribution into two groups exceptionally, being them the risk and low risk groups; that will be taken into account the diagnosis and some prognostic factors. Thus, the criteria for naming groups are essential for this subdivision (ELMAN and SILVA, 2007).

The low-risk group are patients aged 1 year or older and less than 9 years; who has leukometry lower than $50000 / \mathrm{mm} 3$ at the initial diagnosis and less than $5000 / \mathrm{mm} 3$ on the seventh day of treatment and predominantly presents absence of peripheral blasts and low spinal cord involvement on the fourteenth day of treatment, besides presenting the medulla with low leukemic cell count) on the twentieth day of induction; if there is the presence of central nervous system (CNS) involvement at diagnosis, therefore, there should be no blasts on cerebrospinal fluid examination on the fourteenth day of treatment (CAZÉ, etal., 2010).

However, the group called high risk are patients with 
4 Costa, E.J.B.; Lima, A.F.P.S.; Silva, E.T.B.; Silva, E.B.; Lima, J.B.A.S.; Silva, M.T.B.; Silva, W.C.; Silva, V.D.B.; Silva, G.E.R.; Souza,

J.M.; Albuquerque, V.H.; Aguiar, A.C.; Silva, R.M.S.; Lima, C.G.O.; Bruce, J.C.S.; Costa, L.L.L.; Silva, E.V.; Barbosa, V.C.; Gomes, V.S.; Alvares, E.B.S.O.; Aguiar, M.J.L. Acute lymphocytic leukemia in children: revision and use of clinical forms of treatment by means of medication...

mean age, less than 1 year and greater than or equal to 9 years; who have leukometry greater than $50000 / \mathrm{mm} 3$, from the diagnosis and have a slow immunological response, to treatment, in what confers, the leukocyte count, is usually greater than or equal to $5000 / \mathrm{mm} 3$ on the seventh day of treatment and obtains the presence of leukaemic blasts in peripheral blood on the fourteenth day of treatment, there is also an extensive medullary involvement, also on the fourteenth day, besides presenting evidence of extramedullary leukemic involvement at the end of the treatment induction process (SANTOS, 2017).

It is of paramount importance to subdivide these groups, so that it can separate the most effective method for each degree of the patient affected by neoplasia, therefore, the drug regimens and doses for the low and high-risk groups are predominantly, made in different ways. The dosages of the components of the intrathecal chemotherapy process, for example, are specific for each degree of the disease (CAZÉ, et al., 2010).

According to studies at the Hospital das Clínicas de Porto Alegre, Cazé et al, 2010, came to the conclusion of the way patients were treated through this protocol, thus classifying the methods, doses, treatment days and groups that were medicated with the drugs, deliberately used by the GBTLI-99 Protocol.

The drugs used for this Protocol are Metactate, Cytarabine and Dedhashasone, consequently, the doses used of the components of the combination, combination of metactorabine, cytarabine and dandhasone administered inthemecalmente (MADIT), are adjusted according to the age of the patients (ELMAN and SILVA, 2007).

The process of using medications and doses specified in the GBTLI-99 protocol for the treatment of ALL patients at low risk of relapse consists of four stages; Induction of remission that lasts about four weeks and the drugs used and their doses are Prednisone, Vincristina, L-asparaginase, Daunorrubicin and MADIT (SANTOS, 2017).

In the stage Consolidation of remission that reaches last about two weeks of treatment, and the drugs and their doses are; Cyclophosphamide, Cytarabine, 6-Mercaptopurine and MADIT. In the intensification stage that can last about 8 weeks, medications are used; Methorexate, 6Mercaptopurine with dose and MADIT. Regarding, in the stage and late consolidation, with an average duration of 8 weeks, the medications used are Dhimamethasone, Vincristina with Doxorubicin, L-asparaginase, Cyclophosphamide, Thioguanine and MADIT (CAZÉ, et al., 2010).

Regarding the medications and doses specified in the GBTLI-99 protocol for the treatment of ALL patients in the high-risk group of relapses, are done in several stages, the induction of remission lasts about 4 weeks with medications Prednisone, Vincristina, L-asparaginase, Daunorrubicin and Methodrex. The Consolidation stage with a lasting treatment of 1 week, the following medications are used; Methodism, Tioguanine, Cytarabine and Cyclophosphamide. In the
Intensification stage lasting 8 weeks of treatment, the following medications are used; Dhimhasone, Vincristina, Doxorubicin, L-asparaginase, Cyclophosphamide, Cytarabine and Thioguanine (SANTOS, 2017).

However, the process of therapeutic and pharmacological treatments is used with the central objective of aggregating as many patients with survival as possible. Therefore, even if thereis noGBTLI-LLA99 protocol, there are no concrete instructions, that is, an order or time of use of medicines, when they are administered it is necessary to present a schedule of antineoplastic drugs administered daily so that they can analyze and know the progress of treatment (CAZÉ, et al., 2010).

\section{Conclusions}

The article was based on the narrative of understanding the therapeutic treatments of pharmacological in children and adolescents who are affected by Acute Lymphocytic Leukemia (ALL). For this, it was necessary to understand which groups this neoplasm affects, as well as the ways that it is possible to know the diagnosis and, consequently, perform the correct treatment for each degree of the disease, thus using drugs that present a gradual decrease of the disease.

Thus, ALL is a neoplasm that requires in-depth studies, so this article was deliberately expected to evaluate the protocols for the effective treatment of the disease, considering the drug administration that is responsible for its regression. Enabling greater chances of cure according to the treatment indicated for each diagnosed case.

In this work it was possible to understand a bibliographic perspective and how the diagnosis is made, what treatments indicated and how the treatment known by GBTLI-99 is done according to the degree that each patient is thus perceived to understand which medications are used, and for how many days the medications are made in the patient, low-risk and high-risk.

\section{References}

[1] ALMEIDA, Tereza Joelma Barbosa. Avanços e perspectivas para o diagnóstico da Leucemia Linfoide Aguda. Candombá - Revista Virtual, v. 5, n. 1, p. 40-55, jan. - jun. 2009.

[2] ABRALE - Associação Brasileira de Linfoma e Leucemia. Leucemia infantil: tratamentos e seus avanços. 2020. Disponível em: https://revista.abrale.org.br/leucemia-infantiltratamento/. Acesso em 20 de outubro de 2021.

[3] CAVALCANTE, Matheus Santos; ROSA, Isabelly Sabrina Santos; TORRES, Fernanda. Leucemia Linfoide Aguda e seus principais conceitos - Revista Científica da Faculdade de Educação e Meio 
Ambiente - Ariquemes: FAEMA. V.8.n. 2. Jul-dez. 2017.

[4] CAZÉ, Marcelino Oliveira; BUENO, Denise; SANTOS, Maria Elisa Ferreira dos. Estudo Referencial de um Protocolo Quimioterápico para Leucemia Linfocítica Aguda - Rev. HCP. 2010.

[5] ELMAN, Ilana; SILVA, Maria Elisabeth Machado Pinto - Crianças Portadoras de Leucemia Linfoide Aguda: Análise dos Limiares de Detecção dos Gostos Básicos. Revista Brasileira de Cancerologia 2007; 53(3): 297-303

[6] FARIAS, Mariela Granero; CASTRO, Simone Martins de - Diagnóstico laboratorial das leucemias linfoides agudas. Medicina Laboratorial - J. Bras. Patol. Med. Lab. 40 (2) abr. 2004.

[7] HAMERSCHLAK, Nelson - Leucemia: fatores prognósticos e genética. Artigos de Revisão • Jornal de Pediatria - Rio de Janeiro Vol. 84. Agosto de 2008.

[8] INCA - INSTITUTO NACIONAL DO CÂNCER. Câncer infanto-juvenil. 2021. Disponível em: https://www.inca.gov.br/tipos-de-cancer/cancerinfantojuvenil. Acesso em: 26 de maio de 2021.

[9] ONCOGUIA - Uso da quimioterapia no tratamento do câncer. 2021. Disponível em: http://www.oncoguia.org.br/conteudo/quimioterapia/ 3701/50/ Acesso em: 26 de maio de 2021.

[10] OLIVEIRA, Benigna Maria de; DINIZ, Michelle dos Santos; VIANA, Marcos Borato. Leucemias agudas na infância. Rev. Med. Minas Gerais, p. 33-39, 2004.

[11] SANTOS, Cleiciqueli do Carmo; RIBEIRO, Jeile Teixeira; TEIXEIRA, Jeinny. Leucemia- sociedade em riscos. Trabalho de Conclusão de Curso. Farmácia. Orientadora: Tânia Paes. 2014. Rolim de Moura/SP.

[12] SANTOS, Marco Hernani Silva - Mortalidade e Fatores associados ao óbito em crianças e adolescentes com Leucemia Linfoide Aguda tratadas em um serviço de referência no Nordeste do Brasil. Trabalho de Conclusão de Curso. Departamento de Medicina - Universidade Federal de Sergipe - UFS. 2017. Aracaju

[13] SILVA, Clarice de Sousa; SOUSA, Rogerio Rodrigues; CARDOSO, Rafael Oliveira. Leucemia linfocítica aguda na infância e suas complicações. Revista de Iniciação Científica e Extensão, v. 1, n. 2, p. 109-113, 2018.
[14] SILVEIRA, Neiva Albertina; ARRAES, Sandra Mara Alessi Aristides. A imuno fenotipagem no diagnóstico diferencial das leucemias agudas: uma revisão. Arquivos do Mudi, v. 12, n. 1, p. 5-14, 2008. 